378.147::811.163.41(477)

https://doi.org/10.18485/msc_saopstenja.2018.48.1.ch8

Леся М. СТЕБЛИНА*

Прегледни рад

Київський університет імені Тараса Шевченка

Примљен: 18. 11. 2018.

Институт филологии

Прихваћен: 03. 12. 2018.

\title{
СРПСКИ ЈЕЗИК И КЬИЖЕВНОСТ НА КИЈЕВСКОМ УНИВЕРЗИТЕТУ „ТАРАС ШЕВЧЕНКО” - ИЗАЗОВИ САВРЕМЕНОГ ДОБА
}

\begin{abstract}
Изучавање српског језика и књижевности у оквиру специјализације „српскохрватски језик и књижевност” у Украјини започето је у новије време 1973. године на Кијевском националном универзитету „Тарас Шевченко”. Од 1993. сваке друге године студенти уписују специјализацију „српски језик и књижевност”. За ово време образован је бројни стручни кадар, бивши студенти раде у различитим државним и приватним институцијама - Академији наука, Министарству спољних послова, на универзитетима, у медијима. Нажалост, у последње време због различитих околности интересовање друштва за славистичке смерове се смањује, а и реформе образовања изискују промене у прилазима класичној настави инословенског језика и књижевности.

Кључне речи: српски језик и књижевност, инословенски језик, наставни програм, украјинска србистика.
\end{abstract}

Питање интересовања за српски језик и књижевност у универзитетској средини у савремено доба део је веће теме која је већ неко време актуелна на свим универзитетима, у свим европским земљама - а то је статус славистике у савременом глобализованом свету. Велике друштвено-историјске промене у словенским земљама, демографски проблеми, формирање новог информационог простора, општа криза хуманистике и „рационализација” живота довели су до опадања интересовања младих људи уопште за хуманистичке науке, посебно за словенске језике и књижевности. Савремене прилике изискују потрагу за новим, бољим моделима образовања и променама у прилазу настави. Овај проблем је последњих година био у средишту пажње бројних научних састанака, конференција, о томе се расправљало и на XVI међу-

*steblyna_lesja@ukr.net 
народном конгресу слависта у Београду, посебно на заседањима Комисије из методике наставе словенских језика, књижевности и културе. О томе се пише у научним публикацијама, о томе сведочи и бројност стручњака који су се одазвали на овогодишњи позив Међународног славистичког центра да се расправља о стању и перспективама српског језика, књижевности и културе на страним универзитетима. Чини се да ми сви трагамо за позитивним одговором на питање којим је насловио своју публикацију у Украјини професор Дејан Ајдачић, светски слависта који више година ради на нашем универзитету као лектор српског језика и књижевности: „Коме је данас потребна славистика?" (Ајдачић 2010). И то питање се на сличан начин поставља у различитим земљама, актуелно је и у Пољској, и у Русији, и у Бугарској, наравно, и код нас у Украјини, где се српски језик и књижевност као посебна специјализација проучава на Кијевском универзитету „Тарас Шевченко” и Лавовском универзитету „Иван Франко”.

Као што се види из резимеа учесника нашег научног скупа (МСЦ, 48/2018), српски језик и књижевност имају различити статус на разним универзитетима, а историја србистике почиње у високошколским установама у различито време, већином 90-их година. Код нас упис студената на посебну двоструку специјализацију „српски језик и књижевност, украјински језик и књижевност" такође почиње од 1993. године, мада су се и пре тога српскохрватски језик и књижевност југословенских народа изучавали као посебна струка неколико година.

Кијевски универзитет „Тарас Шевченко”, као висока школа класичног типа, има дуготрајну и плодну историју славистике. Славистичка катедра је била једна од првих на универзитету Светог Владимира. Основана је 1842. године као Катедра историје и књижевности словенских наречја. На самом почетку изучавање словенских језика било је неопходан предуслов за проучавање књижевности, историје и културе словенских народа. Прве податке о настави српског језика на Кијевском универзитету имамо из друге половине XIX века. Повезани су с Александром Котљаревским, бившим студентом једног од првих источнословенских слависта Осипа Бодјанског, професора Московског универзитета и иначе покретача изучавања живих словенских језика у инословенској средини. У распореду часова 1878-1879. наставне године налазе се бугарска и српска књижевност, а 1880-81. - словенски језици, укључујући и српски (Бубнов 1907). У школској 1909-1910. години предају се „Поредбена граматика словенских језика” и „Српскохрватски језик”, лекције држи професор А. Лукјаненко (Преглед 1909). Због револуција, ратовања, репресија према славистима, као и бројних реорганизација више школе дошло је до прекида у развоју славистике. Тек 1947. године катедра је била обновљена. Прво су се припремали полонисти и бохемисти, а од 1961. почиње факултативни курс српскохрватског/српског језика за студенте украјинистике и русистике. Упис студената на посебну специјализацију „српскохрватски језик и књижевност" отпочиње 1973. и траје све до 1993. године, откад се групе студената-србиста паралелно с бугаристима уписују сваке 
друге године наизменично с групама кроатиста (паралелно - група за чешки језик и књижевност) (Стеблина Рудјакова 2010).

Почевши од 1973. до 2015. настава се комплетно спроводила у оквирима филолошког образовног профила. Под широким називом дисциплине „Основни словенски језик” прва 3 семестра студенти су стицали комуникативну компетенцију, а затим је следило системско проучавање језика - фонетике и фонологије, морфологије, синтаксе, стилистике. Крајем 90-их у наставни програм се укључују специјални курсеви који проширују знања студената о српском језику - „Историја књижевног језика”, „Историјска граматика”, „Творба речи”, „Лексикологија српскога језика”, „Српска лексикографија”, „Фразеологија”. Основе преводилачке компетенције добијају се на курсевима „Теорија и пракса превођења”, „Специфичности превођења с украјинског на српски и обрнуто” и др. По дипломирању студенти би стицали право да се запосле као наставници српскохрватског (даље српског) језика и књижевности, или украјинског језика и књижевности.

У исто време, српски језик се предавао (то важи и сада) као други словенски језик студентима бохемистима и полонистима, те као инословенски језик за студенте украјинисте, а једно време у другој половини 90-их година факултативно студентима-историчарима.

И тако је време „процвата наставе инословенских језика” трајало приближно до почетка друге деценије 21. века. Славистика је била тражена струка код матураната, сваке године смо имали конкурс приликом пријемних испита и уписа, уводили нове наставне курсеве, смењивали су се нови инословенски језици као први (словеначки, белоруски), други, чак и трећи - словачки, македонски. Једно време је наша катедра бројала до 25 људи укључујући стране лекторе. Нормативне и специјалне курсеве србистике изводило је пет украјинских наставника, и то Олена Дзјуба, Лесја Стеблина, Олена Деркач, Наталија Билик, Лесја Петровска и српски лектор проф. Дејан Ајдачић.

Дакле, припрема стручњака из српског језика и књижевности дуже време се остварује у правцу формирања професионалне компетенције дипломираних филолога, чије су саставне компоненте теоријско-лингвистичка, преводилачка, комуникативна, културолошка, психолошко-педагошка. Главни фактор који је одређивао прилаз настави је филолошки образовни профил у којем српски језик има статус главне нормативне наставне дисциплине (напоредо са књижевношћу) и у процесу наставе функционише као објекат научне анализе, средство комуникације и медиј за усвајање нових знања (Кончаревић 1996).

Колико је нама познато, исти класични универзитетски принцип важи и за украјинистику у Београду, мада се овде, осим статуса основне специјалистичке дисциплине, украјински предаје и као други (трећи) и изборни страни језик студентима различитих специјализација, што се разликује од наставних принципа у организацији више школе у Украјини.

Промене интересовања за инословенске језике у украјинском друштву почеле су се осећати још у првој деценији 21. века. Општи заокрет према примењеној хуманистици у образовању имао је за последицу смањење ин- 
тересовања за славистику. Социјалне, еконономске, технолошке промене у земљи неизбежно нас сваке године приликом уписа суочавају с најјачим изазовом савременог доба - смањивањем броја матураната и окретањем оних, којих још има, према професијама које су на први поглед „конкретније”, „траженије” у друштву, код којих се лакше може прогнозирати посао, чиме hе се студент бавити након универзитета и колико је то занимање исплативо. Наша катедра словенске филологије настоји да се придржава филолошког образовног профила и у новим приликама, мада и с извесним модификацијама упркос предлозима и покушајима да се трансформишемо са двојезичних (тројезичних) студија у двопредметне (тропредметне), како се то, истине ради, догодило у другим срединама. Комбинације учења страног (у нашем случају инословенског) језика с изучавањем историје матичне земље, на којој је распрострањен дати језик, или читаве регије, међународних одноca, културологије, историје уметности, филмологије, налазе се на почетку пописа предлога за реформисање класичне филологије. Није да не желимо да прихватимо промене, већ хоћемо да се у тим променама очува класично универзитетско схватање учења језика и књижевности као феномена народа, формираних и његовом историјом, и културом, и кинематографијом, и уметношћу, па и међународним односима и контактима. Да не говоримо и о томе да се број наставних часова не сме повећавати. Све промене код инословенског језика и књижевности спроводе се укидањем курсева из књижевности, али и специјалних лингвистичких дисциплина као што су „Лексикологија”, „Фразеологија”, „Историја књижевног језика”, „Историјска граматика”. Колико је нама познато, класични универзитетски приступ изучавања филологије важи и за украјинистику у Београду, мада се овде, поред статуса основне дисциплине, украјински предаје као други (трећи) и изборни страни језик студентима различитих специјализација, што се разликује од концепције организовања више школе у Украјини.

Од 2015. године, у потрази за осавремењивањем стручне понуде и привлачењем већег броја матураната, реформисали смо наставни план и увели „превод” као један од саставних делова специјализације напоредо са српским и украјинским језиком и књижевностима. У том циљу смо у блок дисциплина за слободни избор студената од три специјализације додали и низ нових предмета који би допринели стручној припреми наших студената за будуће преводиоце: „Преводилачка анализа текста”, „Теоријски и примењени аспекти превођења”, „Граматичке особине превода са српског на украјински и обрнуто”, „Морфолошки, лексички, синтаксички проблеми превођења”, „Врсте усменог превођења са српског језика”, „Међусловенски превод у условима глобализације”, ,Лингвокултуролошка компетенција преводилаца са српског језика”, а за будуће наставнике и научне раднике - „Најновије тенденције развоја српске књижевности”, „Историја и савремено стање лингвистичке славистике”, „Српска фразеологија у етнолингвистичком аспекту”, „Савремена српска књижевност у контексту културе”, „Социолингвистичка карактеристика западнојужнословенског језичког простора” и друге. Такве 
промене су нам ипак дозволиле да останемо у ширим границама филологије као науке.

Проблем смањеног броја матураната за упис није настао јуче нити се тиче само група са српским језиком, нити само Украјине. Корен му је у сложеној демографској ситуацији у многим земљама. Код нас су приликом уписа у почетку мало боље пролазиле групе с чешким и пољским језиком, али је то сада већ прекорачено. Наши матуранти масовно одлазе на студије у Украјини блиске земље Европске уније - Пољску, Чешку, Словачку па и даље, које су због мањка својих студената јако заинтересоване за њих. Ако је раније за студије у иностранству било потребно или да плате студије или да прво науче језик па положе испите приликом уписа, сада се тенденција променила. Велики број ученика старијих разреда у Украјини још је пре матуре опредељен за студирање и даљу потрагу за бољим животом у иностранству. То сваки дан запажамо у својој ближој околини.

Ситуација се драстично погоршава тиме што се у истом овом периоду реформише начин спровођења конкурса тако што се приликом уписа на факултете смањује број места за бесплатно студирање и подстичу родитељи и студенти да сами финансирају студије за струке које су популарне и „профитабилне”. У таквој ситуацији класични прилаз настави не може да преживи без подршке. Сутра или прекосутра ипак ћемо морати да жртвујемо нешто или некога. Због таквих неповољних прилика 2016. године први пут за све ове године нисмо оформили групу за српски језик, јер су од више пријављених бесплатна места добила само два кандидата, а у групи за бугарски језик и књижевност три. На крају смо, од толико малих група, уз сагласност студената и родитеља, отворили само једну, бугарску групу. И то иде напоредо са три групе од по десет студената-полониста, који су били боље рангирани од „наших” на конкурсној листи.

Ове, 2018. године Катедра је опет уписивала „бугаристе” и „србисте”. За специјализацију „српски и украјински језици и књижевности” пријавило се више од 40 матураната. Међутим, опет смо добили само 3 бесплатна места (уместо очекиваних 5-6) од којих су 2 претендента одустала (и та места су пропала) јер су се одлучили да студирају међународне односе и новинарство. Слична се ситуација догодила и са „бугаристиком”. Морали смо интервенисати да некако покушамо да поправимо ситуацију. Контактирали смо са оним матурантима који нису прошли, као и са њиховим родитељима па на тај начин успели да приволимо 2 студента који би сами себи платили студије и тако опет уместо 2 отворили на крају једну групу од 5 полазника са српским језиком и књижевношћу као основном специјализацијом. Да више не бисмо доводили у питање наше славистичке групе, од следеће године ћемо увести енглески као трећи језик специјализације јер он још увек остаје својеврстан „мамац” за матуранте.

Још један изазов за кијевску универзитетску славистику чини прилагођавање украјинске више школе Болоњском систему, или, тачније, оне модификације које је попримила у нашим условима та првобитно позитивна идеја слободног приступа образовним системима и културној баштини раз- 
личитих земаља, формирања општеевропског образовног простора преко развоја мобилности студената и професора, проширења могућности за младе људе да студирају на универзитетима других земаља (програм Еразмус +) и каснијег признавања њихових диплома широм Европе и света, међусобне конкуренције европских образовних институција, подизања улоге универзитета у стварању националних и општеевропских културних вредности. С друге стране, увођење кредитно-модулног принципа организације наставе (у којем се $30 \%$ од општег броја часова користи за лекције и вежбе) напоредо са скраћивањем броја лекција због малих група и повећањем удела „самосталног рада студента" на курсевима инословенских језика и књижевности, успостављање суодноса броја студената и професора 18:1, традиционална зависност броја радних места за наставнике и професоре на катедри од броја наставних часова доводе до проблема с формирањем инојезичних компетенција младих слависта а и до отпуштања професора. Нажалост, таква ситуација угрожава не само домаћи педагошки славистички кадар, него и стране лекторе који раде код нас на катедри, нарочито оне који немају институционалну и финансијску подршку од својих земаља-матица. Код нас су то засад лектори словеначког, белоруског и српског језика и књижевности. Лектори из Бугарске и Хрватске на сваке три године након конкурса потписују уговоре са својим Министарствима образовања о раду на месту лектора у иностранству и добијају осим украјинске месечне зараде финансијску накнаду од своје земље.

У расправи о институционалној и државној подршци проучавања језика и књижевности неког народа (било српског, било украјинског, било неког другог) у иностранству важно је нагласити да не може један толико важан посао одржавања присутности (српске, украјинске...) културе, језика и књижевности у другој земљи бити само на леђима ентузијаста или зависити од прилика унутар те земље. Подршке никад није мало, увек може бити више и боље.

У нашим приликама не можемо рећи да смо запостављени од стране Сpбије. Сваке године добијемо од МСЦ-а једну бесплатну студентску стипендију за учешће на Скупу младих слависта и позиве за професоре; такође, сваке друге године преко међууниверзитетског уговора доводимо на Београдски универзитет групу од 15 студената на двонедељну размену, а професори долазе на стручно усавршавање, библиотека српских издања стално се попуњава вредним издањима захваљујући сарадњи са Иваном Николић и Народном библиотеком Србије. Фонд српских речника на катедри богатији је него у Националној научној библиотеци Украјине. Велики подухват је остварен преко лета 2018. године када су напокон прорадили међудржавни договори и наша су Министарства образовања и науке разменила стипендије од 3 до 12 месеци за српске и украјинске студенте и постдипломце. Претенденти су по свом избору могли одабрати универзитет у Србији (Украјини), осигуран им је бесплатан смештај у студентским домовима, исхрана, стипендије. Са нашег универзитета на Универзитету у Београду по том програму сада студирају два студента, а ми у Кијеву очекујемо долазак једног српског украјинисте. Верујемо да је то тек почетак. 
Такође, стално смо у контакту и увек наилазимо на разумевање и добијамо подршку Амбасаде Републике Србије у Украјини - од помоћи за организацију научних конференција, презентацију нових издања, штандова Србије на образовним сајмовима у Кијеву, обезбеђење виза за дужи боравак наших студената у Србији, гостовања српских украјиниста и украјинских србиста у Амбасади до алармирања због угрожености србистике. Процењујући наше савремене прилике, сматрамо да би озбиљна подршка украјинској србистици могло бити отварање Центра за српски језик и културу на нашем универзитету (по примеру бројних центара на нашем Институту филологије) који би не само студентима славистике већ и широј јавности, презентовао Србију и српску културу у Кијеву и Украјини, пропагирајући добронамерност и пријатељство међу нашим народима.

Дакле, на крају друге деценије 21. века србистика на Кијевском универзитету „Тарас Шевченко” нашла се пред више изазова који угрожавају њен даљи развој и опстанак. Таква се ситуација формирала под утицајем неколико фактора - од демографских проблема, дубоких социјално-економских промена у друштву, изгубљене конкуренције са страним универзитетима на „отвореном" општеевропском образовном простору до реформе образовног система у условима слабљења финансијских средстава, смањивања интересовања за славистику уопште, окретања матураната према тренутној „прагматичности” и „профитабилности” струка. Решења насталих проблема и налажење правог начина и пута за очување србистике и славистике морају се, уз подршку са српске стране, тражити унутар украјинске више школе. Она су могућа, према нашем мишљењу, преко измена у Наставном плану за припрему украјинских србиста у правцу осавремењивања образовне славистичке понуде универзитета. У организационом смислу то подразумева формулисање јасних правила уписа на универзитет уз одређивање фиксне количине места на буџету за славистичке групе, као и укидање „економичности” наставних часова на „малим” групама. С друге стране, продужење и интензивирање подршке украјинској србистици од стране Србије омогућиће ширу промоцију српске културе у Украјини, а обезбедиће и услове да се сачува висок професионални ниво студија српског језика и књижевности на Кијевском универзитету „Тарас Шевченко”.

\section{ЛИТЕРАТУРА}

Ајдачић 2010: Д. Айдачич, Кому потрібна славістика сьогодні?, у: Славістичні дослідження: фольклористичні, літературознавчі, мовознавчі, Київ: Видавничо-поліграфічний центр „Київський університет”, 3-12.

Бубнов 1907: Н. Бубнов, Общие учебные планы и правила историко-филологического факультета Университета Св. Владимира сост. Деканом Н. Бубновым 19 мая 1907 г., Киев: Универс.типография. 
Кончаревић 1996: К. Кончаревић, Настава страног језика на филолошким студијама: теорија и пракса, Београд: Филолошки факултет.

МСЦ-48 2018: Тезе и резимеи / 48. међународни научни састанак слависта у Вукове дане, Београд 13-17. IX 2018; (уредници Драгана Мршевић-Радовић, Бошко Сувајџић), Београд: Филолошки факултет, Међународни славистички центар.

Преглед 1909: Обозрение преподавания на историко-филологическом факультете императорского Университета Св. Владимира в весеннем полугодии 1909 г., Киев: Типография университета.

Стеблина Рудјакова 2010: Л. М. Стеблина-Рудякова, Сербістика в Київському університеті імені Тараса Шевченка, у: Д. Айдачич (ред.), Українсько-сербський збірник УКРАС, вип.1(4), Київ, 202-223.

СЕРБСКИЙ ЯЗЫК В КИЕВСКОМ УНИВЕРСИТЕТЕ ИМЕНИ ТАРАСА ШЕВЧЕНКО ВЫЗОВЫ СОВРЕМЕННОСТИ

\section{Резюме}

В статье идет речь о проблемах преподавания сербского языка и литературы в Киевском национальном университете имени Тараса Шевченко на современном этапе. С момента возрождения изучения инославянских языков в университете преподавание осуществлялось в рамках филологического образовательного профиля. Необходимость реагирования на вызовы современности, перед которыми оказалась сербистика и шире славистика - снижение интереса абитуриентов к изучению славистических дисциплин, отток выпускников школ в более развитые и стабильные страны Европы, реформирование системы образования и разработка новых правил зачисления абитуриентов, введение Болоньской системы в украинскую образовательную систему, - выражается в поисках современных и адекватных изменений в подходах к преподаванию инославянского (сербского) языка а также поддержки со стороны Сербии.

Ключевые слова: сербский язык и литература, инославянский язык, учебный план, украинская сербистика. 